\title{
Journal of \\ Diabetes and Obesity \\ Effective of Red Ginseng Extract on Ameliorate Adipogenesis 3t3-L1 by Decreasing P38 and Erk Phosphorylation
}

\author{
Seon Mi Ko, Seung-Mi Hwang, Dongjoong Im, Kyung-Min Choi*, Gi-Beum Kim* \\ Institute of Jinan Red Ginseng, 41 Hongsamhanbang-ro, Jinan-eup, Jinan-gun, Jeonbuk, 55442 Republic of Korea
}

"Corresponding author: Gi-Beum Kim, Institute of Jinan Red Ginseng, 41 Hongsamhanbang-ro, Jinan-eup, Jinan-gun, Jeonbuk, 55442 Republic of Korea, E-mail: kgb70@jbnu.ac.kr

Kyung-Min Choi, Institute of Jinan Red Ginseng, 41 Hongsamhanbang-ro, Jinan-eup, Jinan-gun, Jeonbuk, 55442 Republic of Korea, E-mail: kyungmc@ijrg.re.kr

\begin{abstract}
This study examined the anti-obesity effect and mechanism of action of red ginseng extract (RG) in 3T3-L1 cells. To measure the levels of lipid accumulation, we were observed of expression of genes and proteins, which is associated with adipocyte differentiation in 3T3-L1 cells. Eight days following induction for differentiation with MDI-medium and simultaneously with the tested RG, our study found significantly reduced $(\mathrm{p}<0.05)$ intracellular triacylglycerol accumulations of 3T3-L1 cells by does dependent manner. RG decrease adipogenic markers, C/ $\mathrm{EBP} \alpha, \mathrm{C} / \mathrm{EBP} \beta$ and PPAR $\gamma$, which is a key regulator of adipocyte differentiation. In this study showed that $\mathrm{C} / \mathrm{EBP} \beta$ is regulated $\mathrm{RG}$ decreased the phosphorylations of p38 mitogen-activated protein kinase (MAPK) and extracellular signal-regulated kinases (ERK). These results suggest that the anti-adipogenic effect of RG in 3T3L1 pro-adipocyte could be associated with the inhibition of adipogenic transcription factors by regulations with p38 MAPK and ERK phosphorylation.
\end{abstract}

Keywords: Red ginseng extract: Anti-obesity effect; 3T3-L1 cells; p38; Mitogen-activated protein kinase; Extracellular signal-regulated kinases

\section{Introduction}

Botanical medicines have been applied for the treatment of various human diseases with thousands of years of history in Asia and are sharing a large market in the form of drugs, dietary supplements, and foods. In the west, botanical medicines are categorized as complementary/alternative medicines, dietary supplements, or foods. Ginseng, referred to as the root of Panax ginseng Meyer (Araliaceae), is one of the most valuable medicinal plants, particularly in Korea, China, and Japan ${ }^{[1]}$. Ginseng has been used as a valuable tonic and for the treatment of various diseases $^{[2]}$. The pharmacological properties of ginseng are mainly attributed to ginseng saponins, commonly called ginsenoisdes, the major and bioactive constituents ${ }^{[3]}$, With the development of modern chromatography, there are more 40 ginsenoisdes such as ginsenoisdes Rb1, Rb2, Rg1, Rd, and Re identified from ginseng up to date Botanical characteristic ${ }^{[3,4]}$.

Ginseng is a well-known medicinal plant used in traditional Oriental medicine. It has long been known to possess a va-
Received date: November 21, 2016

Accepted date: February 08, 2017

Published date: February 13, 2017

Citation: Kim, G.B., et al. Effective of Red Ginseng Extract on Ameliorate Adipogenesis 3T3-L1 by Decreasing P38 and Erk Phosphorylation. (2017) J Diab Obes 4(1): 1- 5.

DOI: $10.15436 / 2376-0494.17 .1233$

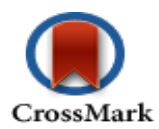

riety of beneficial pharmacological effects, such as enhancement of immunity, inhibition of inflammatory response, and hyperlipidemia and diabetes prevention ${ }^{[5-8]}$. Red ginseng has been heat steamed and dried. As a consequence of this process, red ginseng undergoes certain biochemical chances ${ }^{[9]}$. However, some studies to show that it possesses pharmacological properties like immunomodulatory and anti-cancer effects ${ }^{[10,11]}$.

Obesity is one of the greatest public health problems and major risk factors for serious metabolic diseases and significantly increases the risk of premature death ${ }^{[12,13]}$. Various anti-obesity medications have been developed, including orlistat, lorcaserin, and sibutramine. But, these medications can limit long term use, those have serious side effects such as steatorrhea, high blood pressure, constipation, insomnia, and hepatotoxicity ${ }^{[14,15]}$. Thus, novel preventive and therapeutic options with greater efficacy and fewer side effects are needed.

The MAPK/ERK pathway regulates the control of cell survival and proliferation. The MAPK/ERK signaling cascade is organized hierarchically into a three-tiered module composed

Copyrights: (C) 2017 Kim, G.B. This is an Open access article distributed under the terms of Creative Commons Attribution 4.0 International License. 
of MAPKKK (Raf), MAPKK (MEK1/2) and MAPK (ERK1/2). Raf/MEK/ERK signal transduction activate or inactivate is caused the cascade signal in the cell. The cascade reaction of signal is tightly regulated by protein kinases as well as protein phosphatases. P38 MAPK is active in 3T3-L1 fibroblasts and developing adipocyte, and its activity decreases dramatically a crucial mediator of obesity and insulin resistance ${ }^{[16]}$.

\section{Materials and Methods}

\section{Cell culture}

3T3-L1 preadipocytes were purchased from American Type Culture Collection (ATCC). 3T3-L1 preadipocytes were propagated in high glucose DMEM supplemented with $10 \%$ (v/v) FCS (full name) and $1 \%$ penicillin-streptomycin at $37{ }^{\circ} \mathrm{C}$ in a humidified atmosphere having $5 \% \mathrm{CO}_{2}$. Differentiation was induced in confluent cells by replacing DMEM (Dulbecco Modified Eagle Medium) with differentiation media. Differentiated medium was contained $10 \mathrm{mg} / \mathrm{l}$ insulin, $0.5 \mathrm{mM} \mathrm{IBMX}$ (3-isobutyl-1-methylxanthine) and $0.25 \mu \mathrm{M}$ dexamethasone for $48 \mathrm{hrs}$. And then, the medium was replaced with DMEM supplemented with $10 \mu \mathrm{g} / \mathrm{ml}$ insulin (differentiation medium II, DM II) and changed every other day for the following 6 days. Cells were treated with $0,3.8,7.8,15.6,31.3,62.5 \mathrm{mg} / \mathrm{ml} \mathrm{RG}$. To examine whether RG affected the early response on ERK signaling induced by adipogenesis, 3T3-L1 preadipocytes grown to confluence were allowed to grow for an additional $24 \mathrm{hrs}$ and were then switched to a serum-free culture medium for $4 \mathrm{hrs}$. Cells were treated with RG $10 \mu \mathrm{g} / \mathrm{ml}$ insulin, $0.5 \mathrm{mM}$ IBMX, and 0.25 $\mu \mathrm{M}$ dexamethasone for $0-4$ day as indicated elsewhere ${ }^{[17]}$.

\section{Real time-PCR analysis}

Total RNA was extracted by using easy-spin ${ }^{\mathrm{TM}}$ (DNA free) Total RNA Extraction Kit (intron (??)). One microgram of total RNA was subjected to first strand c DNA synthesis with oligo (deoxythymidine) primers and PrimeScriptTM RTase (Takara).

The reaction mixture (contain Oligo dT primer, dNTP mixture, and template RNA) was incubated $5 \mathrm{~min}$ at $65^{\circ} \mathrm{C}$ and then on ice. Prepare reaction mixture add Prime Script Buffer, RNase inhibitor and Prime Script RTase for 1 cycle at $30{ }^{\circ} \mathrm{C}$ for $10 \mathrm{~min}, 42{ }^{\circ} \mathrm{C}$ for $60 \mathrm{~min}, 95$ and $4{ }^{\circ} \mathrm{C}$ for $10 \mathrm{~min}$. The PCR reactions were performed as follows: $5 \mathrm{~min}$ at $94{ }^{\circ} \mathrm{C}$ for $5 \mathrm{~min}$ and $4{ }^{\circ} \mathrm{C}$. PCR reaction was used to AccuPower ${ }^{\circledR}$ PCR Premix ( Bioneer) 30 cycles of $15 \mathrm{sec}$ at $94^{\circ} \mathrm{C}, 40 \mathrm{sec}$ at $55^{\circ} \mathrm{C}$, and $45 \mathrm{sec}$ at $72{ }^{\circ} \mathrm{C}$; and a final extension of $7 \mathrm{~min}$ at $72{ }^{\circ} \mathrm{C}$. The PCR amplicons were then electrophoresed in $1 \%$-agarose gels containing $40 \mathrm{mM}$ Tris, $20 \mathrm{mM}$ glacial acetic acid and $2 \mathrm{mM}$ EDTA buffer.

\section{Western blotting}

Cells were washed twice with cold PBS and were harvested in $200 \mu \mathrm{L}$ RIPA buffer $(150 \mathrm{mM} \mathrm{NaCl}, 1.0 \%$ IGEPAL ${ }^{\circledR}$ CA-630, $0.5 \%$ sodium deoxycholate, $0.1 \%$ SDS, 50 $\mathrm{mM}$ Tris, $\mathrm{pH}$ 8.0) and protease inhibitor (1 mM PMSF, $1 \mathrm{mg} / 1$ leupeptin, $1 \mathrm{mg} / \mathrm{l}$ aprotinin, and $10 \mathrm{mg} / 1$ phosphatase inhibitor cocktail). Cell lysates were centrifuged at $13,000 \mathrm{~g}$ for $30 \mathrm{~min}$ at $4{ }^{\circ} \mathrm{C}$. The protein content of the supernatant was measured by using the BSA protein assay kit (Pierce Chemical Company). Equal amounts of protein for each sample were applied to $10 \%$ SDS-PAGE gels and were electrophoretically transferred to polyvinylidene fluoride membranes. After electrophoresis the nonspecific binding sites in the membranes were blocked with $5 \%$ nonfat dry milk in Tris-buffered solution (15 mM Tris- 150 $\mathrm{mM} \mathrm{NaCl}, \mathrm{pH}$ 7.4) at room temperature for $1 \mathrm{~h}$. After blocking, the membrane was incubated with anti-adepsin, anti-C/EBP $\alpha$, anti-C/EBP $\beta$, anti-PPAR $\gamma$, anti-phospho-ERK1/2, anti-ERK1/2, anti-phsopho-p38, anti-p38 and anti- $\beta$-actin antibodies at $4{ }^{\circ} \mathrm{C}$ overnight. Thereafter, the membrane was incubated with the secondary peroxidase-conjugated anti-rabbit or anti-mouse $\operatorname{IgG}$ at $37^{\circ} \mathrm{C}$ for $90 \mathrm{~min}$. The bands were detected by using an enhanced chemiluminescence kit (Pierce Chemical Company, Rockford, IL)

\section{Statistical analysis}

Data are expressed as means \pm standard errors of the mean (SEMs). Differences between groups were evaluated by analysis of variance (ANOVA) with the Bonferroni post hoc test or by calculation of Spearman's rank correlation coefficient, as appropriate, using Prism 5.03 (Graph Pad Software Inc., San Diego, CA, USA). Statistical significance was set at $\mathrm{p}<0.05$.

\section{Results}

\section{RG inhibits lipid accumulation in 3T3-L1 pre-adipocytes}

We first determined the effects of $R G$ on cell viability. Preadipocytes 3T3-L1 cells were treated with $0,0.0039,0.0078$, $0.0156,0.0312,0.0625,0.125,0.25,0.5,1,2,4 \mathrm{mg} / \mathrm{ml}$ for $24 \mathrm{hrs}$ as the figure $1 \mathrm{~A}$, cell viability was $99.3,97.2,92.4,90.5,90.3$, $83.4,18.9,7.3,7.0 \%$. The cytotoxic effect of RG (up to $125 \mu \mathrm{g} /$ $\mathrm{ml}$ ) in pre-adipocytes was determined using MTT assay at different doses. There was no significant decrease in viability at the tested concentration (figure 1A). To determine the effects of RG on the adipocyte differentiation, 3T3-L1 pr-adipocyte were incubated until 2-day post-confluence (day 0 ) and treated with RG at a concentration of $15.6,31.3,62.5,125 \mu \mathrm{g} / \mathrm{ml}$ for 8 days during a standard adipogenic induction. RG was determined to significantly inhibit lipid accumulation in a dose-dependent manner through the microscopic examination of Oil Red O-stained lipid droplets and through the spectrophotometric quantification of the extracted stain, indicating the inhibition of adipocyte differentiation in 3T3-L1. (figure 1B).

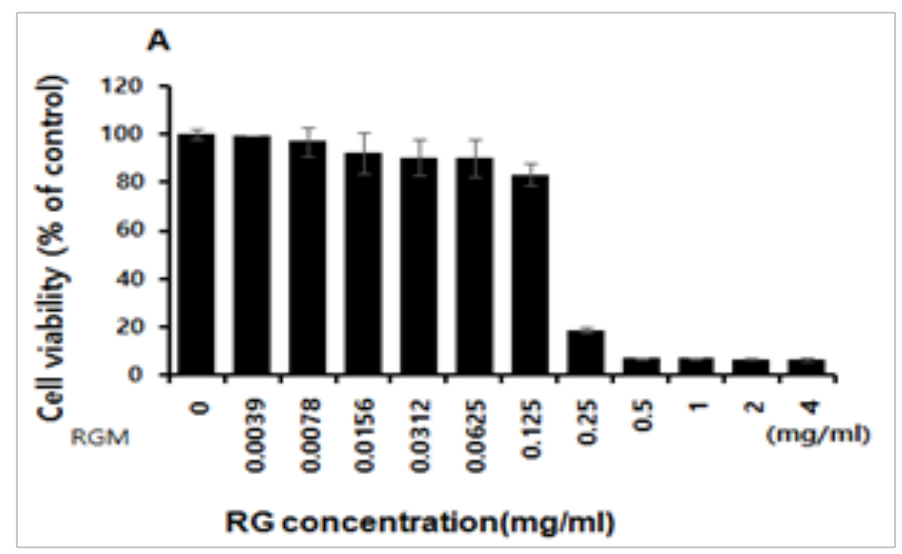




\section{B}

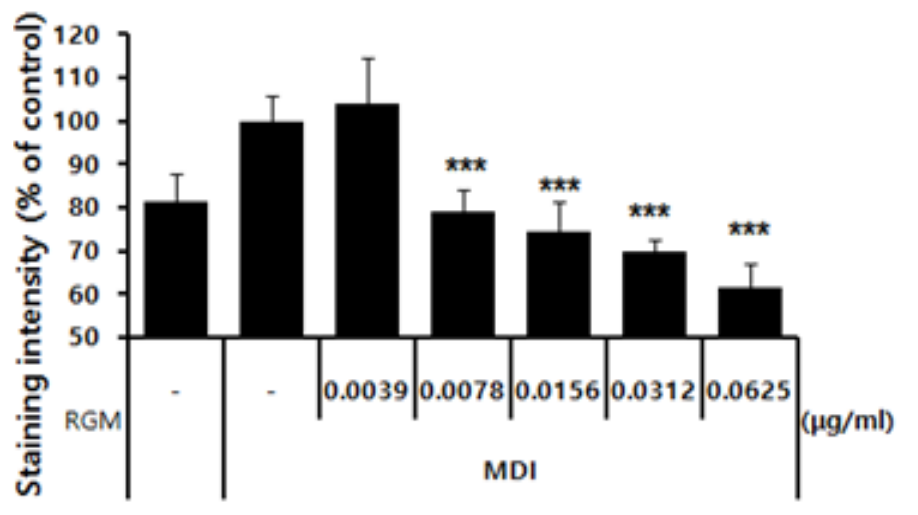

RG concentration $(\mathrm{mg} / \mathrm{ml})$

Figure 1: The cytoxic effect of RG in preadpocytes by MTT assay test in various doses. A; cell viability, B; staining intersisty.
Expression of C/EBPa, C/EBPß and PPAR $\gamma$ are inhibited by RG

Adipocyte differentiation result in a series of programmed alternations of specific genes. Adipogenic is related by adipokines such as PPAR $\gamma, \mathrm{C} / \mathrm{EBP} \alpha$, and $\mathrm{C} / \mathrm{EBP} \beta$ which are known to be critical activators of adipogenesis. In the fully differentiated adipocyte, RG treatment of 15.6, 31.3, 62.5 and 125 $\mu \mathrm{g} / \mathrm{ml}$ decreased C/EBP $\alpha$ and by approximately $0.8,48.1,56$, 46 , and $61.8 \%$ compared to the control. $\mathrm{C} / \mathrm{EBP} \beta$ is decreased by RG $-2.4,22.8,23.6,48.8$, and $71 \%$ compared to the MDI treated only. To determine the change of expression level of protein and mRNA, we accomplished western blotting and RT-PCR. The values above the figures represent relative density of the bands normalized to $\beta$-actin. $\mathrm{C} / \mathrm{EBP} \alpha$ is decreased by $\mathrm{RG}$ at $15.6 \mu \mathrm{g} /$ $\mathrm{ml}$, and $\mathrm{C} / \mathrm{EBP} \beta$ protein level is decreased at $125 \mu \mathrm{g} / \mathrm{ml}$ at 4 days. At the same time, there proteins, which are C/EBP $\alpha$ and $\mathrm{c} / \mathrm{EBP} \beta$, levels are reduced by RG in a dose-dependent manner (Figure 2).
A

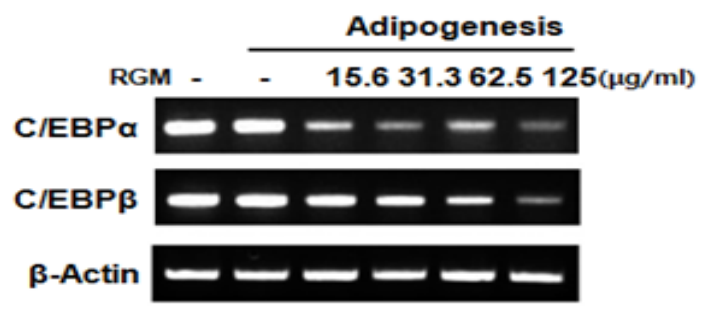

C

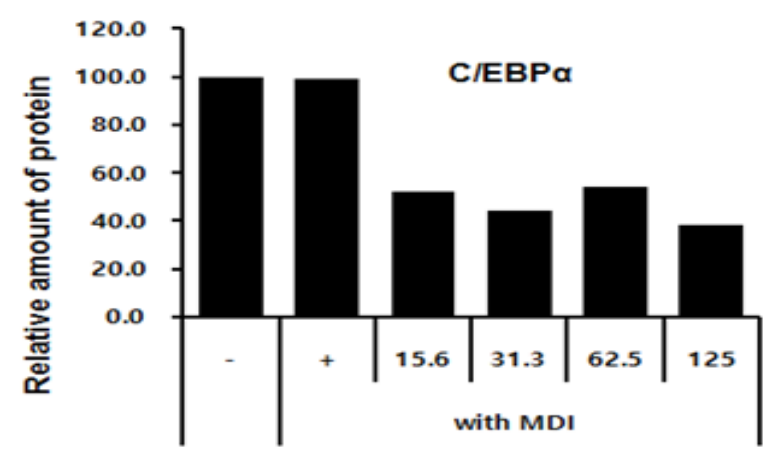

RG concentration $(\mu \mathrm{g} / \mathrm{ml})$
B
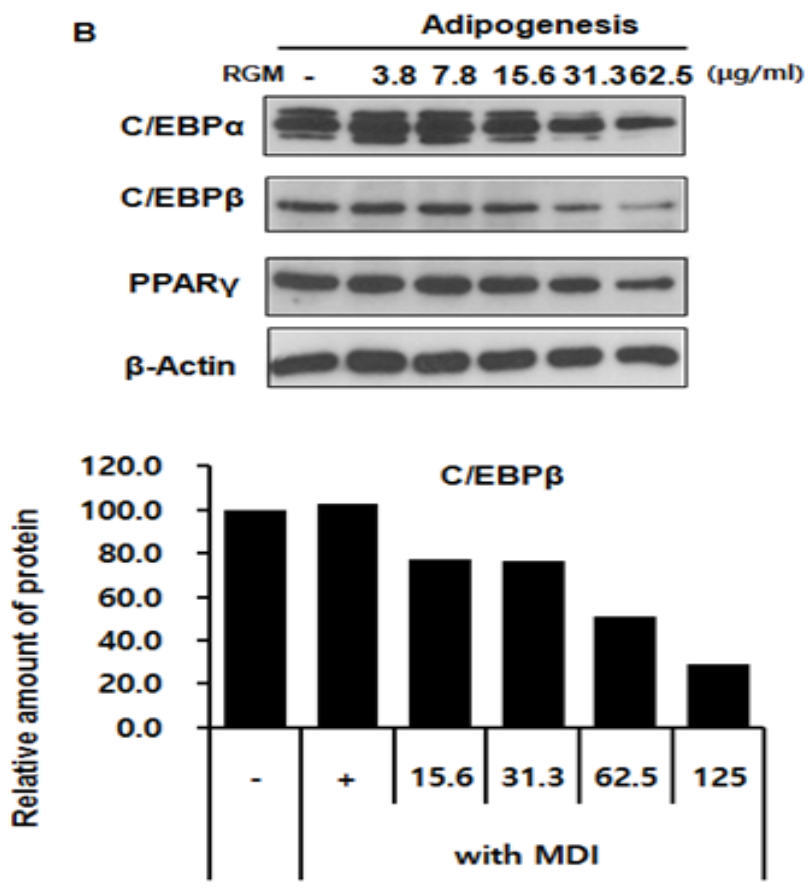

RG concentration $(\mu \mathrm{g} / \mathrm{ml})$

Figure 2: The protein expression of CCAAT enhancer binding protein (C/EBP) $\beta$ and alpha in 3T3-L1 cells incubated with RGM. The 3T3-L1 cells were treated with different concentrations of $\operatorname{RGM}(0,15.6,31.3,62.5,125 \mu \mathrm{g} / \mathrm{ml})$ for 4 day. The upper panels are RT-PCR of C/EBP alpha and beta(A), flod change of C/EBP alpha and beta. The lower panels are western blots of C/EBP alpha, beta, and PPAR gamma.

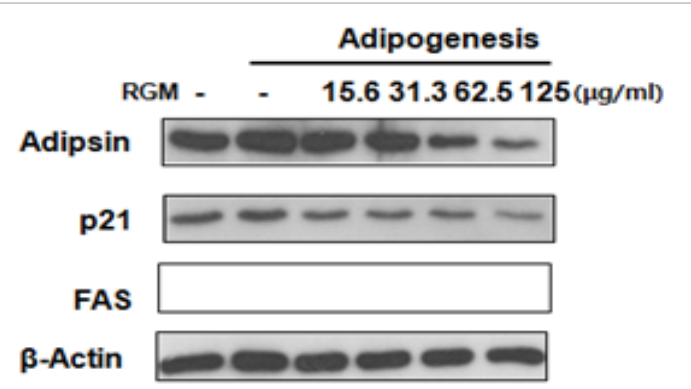

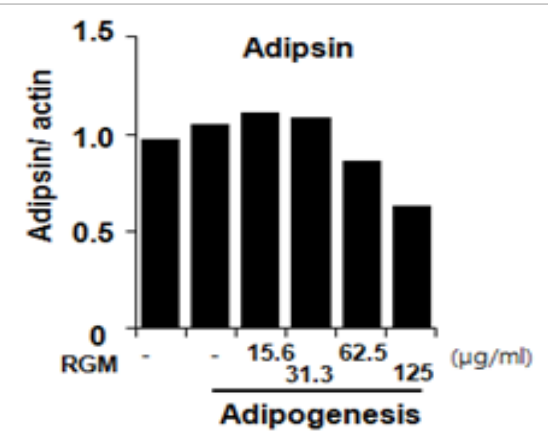

RG concentration

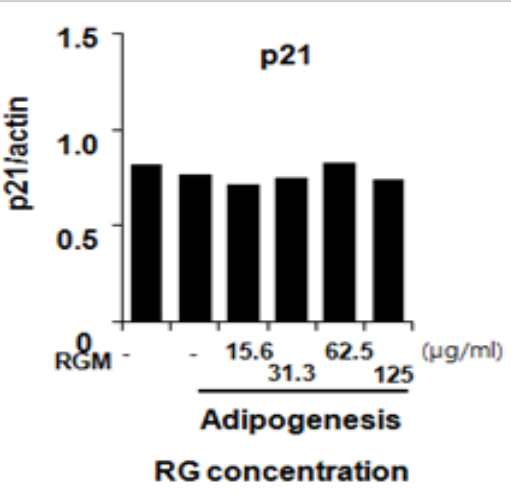

Figure 3: The protein expression of adepsin and p21 in 3T3-L1 cells incubated with RGM. The 3T3-L1 cells were treated with different concentrations of $\operatorname{RGM}(0,15.6,31.3,62.5,125 \mu \mathrm{g} / \mathrm{ml})$ for $4 \mathrm{~d}$ ay. The left panels are western blot of adepsin and p21 (A), and the right panels are fold change of C/EBP alpha and beta. 


\section{Expression of Adipsin and p21 inhibited by RG}

To determine the effect of the RG on expression level of proadipogenic marker, adipsin and p21, western blot assay is performed. p21 and adipsin expression level is reduced by RG, does dependent manner. Adipsin and p21 are decreased by $\mathrm{RG}$ at $62.5 \mu \mathrm{g} / \mathrm{ml}$ and $15.6 \mu \mathrm{g} / \mathrm{ml}$ respectively. (Figure 3), RG treatment of 15.6, 31.3, 62.5 and $125 \mu \mathrm{g} / \mathrm{ml}$ decreased Adipsin by approximately $-7.6,-13.7,-11,11.4$, and $35.4 \%$ compared to the control. p21 protein expression level is reduced by RG, 5.9, $12.4,7.9,-0.7$ and $9.0 \%$ when treated by RG 15.6, 31.3, 62.5 and $125 \mu \mathrm{g} / \mathrm{ml}$ respectively.

The protein expression of p-p38, p38, p-ERK, ERK and $\beta$-actin in 3T3-L1 cells incubated with RG

Adipocyte differentiation and lipolysis were closely related with MAPK proteins. Specially, previous study is reported that $\mathrm{p} 38$ and ERK were regulated adipogensis ${ }^{[18,19]}$. Activated p38 and ERK expression level were decreased by RG in a dose dependent manner. Activated $\mathrm{p} 38$ expression level was inhibited by RG treatment $(15.6,31.3,62.5$ and $125 \mu \mathrm{g} / \mathrm{ml}) 5.9,1.9,1.6$, $11.7,19.7$, and $24.1 \%$. Also, activated ERK is decreased $0,-16$, $-22.3,-5.6,24.5$ and $45.1 \%$ by RG $15.6,31.3,62.5$ and $125 \mathrm{mg} /$ $\mathrm{ml}$ respectively in similar tendency with $\mathrm{p} 38$ reduction. (Figure 4)

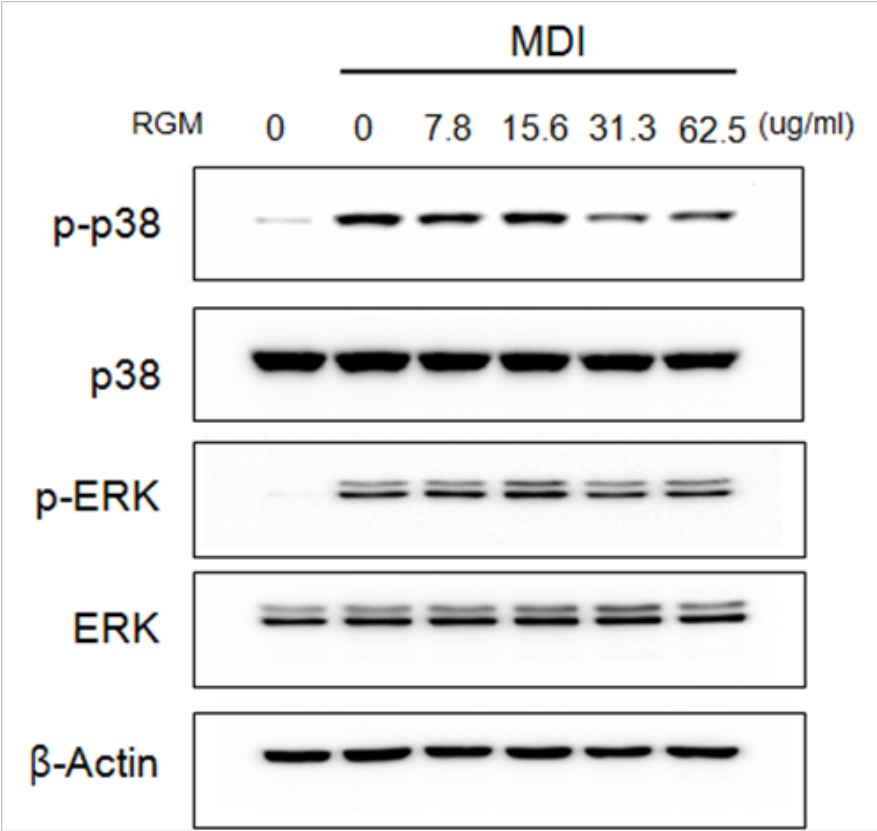

Figure 4: The protein expression of p-ERK, ERK, p-p38, p38 and $\beta$-actin in 3T3-L1 cells incubated with RG. The 3T3-L1 cells were treated with different concentrations of RG $(0,3.8,7.8,15.6,31.3,62.5 \mu \mathrm{g} / \mathrm{ml})$ for 4 days.

\section{Discussion}

Obesity is caused by overabundant fat accumulation and an excess number of adipocyte in adipose tissue and associated with metabolic disease, hyperglycemia, insulin resistance, and cardiovascular diseases. Lipid differentiation is related with adipogenic transcription factors, lipidogenesis factors and adipogenic hormone. One of the key regulator is MAPK signal ${ }^{[20]}$. MAPK signal protein, such as ERK and p38, are regulates cell differentiation and also cell proliferation. Schild, et al. is report- ed that p38 regulates PPAR $\gamma^{[21]}$ Decrease of PPAR $\gamma$ activity lead to reduction of adipsin and $\mathrm{p} 21$, adipogenic marker ${ }^{[22]}$.

In the previous study, red ginseng extracts regulated energy expenditures in adipocyte tissue ${ }^{[23]}$. RG which is remained extract of red ginseng has anti-inflammatory effects, ant oxidative effects and hypoglycemic effect as red ginseng extract ${ }^{[1,24]}$. In this study, we confirmed that red ginseng extract inhibition of adipogenesis in 3T3-L1, preadipocytes cells.

To play a key role in controlling the differentiation of preadipocytes into adipocyte, a cascade of transcription factor expression and activation is well demonstrated. The importance of C/EBP $\alpha, \beta$ and $\delta$ and PPAR $\gamma$ is supported by the finding that white adipose tissue formation is suppressed by gene deletion in C/EBP $\beta-/-\delta$-/- or C/EBP $\alpha$-/- or PPAR $\gamma$-/- knockout mice ${ }^{[15,26]}$. Adipocyte proliferation and differentiation is regulated by adipogenic transcription factors such as PPAR $\gamma, \mathrm{C} / \mathrm{EBP}$ $\alpha$, and C/EBP $\beta$ and the regulator of lipogenic genes SREBP1 (for sterol-regulatory-element binding protein 1) ${ }^{[27-29]}$. RG is reduced the expression of adipogenic transcription factor, PPAR $\gamma$, $\mathrm{C} / \mathrm{EBP} \alpha$ and $\mathrm{C} / \mathrm{EBP} \beta$. This reduction of transcription factors is led by decline of $\mathrm{p} 38$ and ERK activation. Bak, et al. is reported $R G$ concerned with $p 38$ signal in macropage inflammatory reaction $^{[11]}$. This report showed that RG is decreased $\mathrm{p} 38$ and ERK activation too in differentiation of pre-adipocyte 3T3-L1. C/EBP $\beta$ and PPAR $\gamma$ was regulated P38 ad ERK activation (Figure 5). Down regulation of C/EBP $\beta$ and PPAR $\gamma$ caused inhibition of adipogenesis in 3T3-L1 cells.

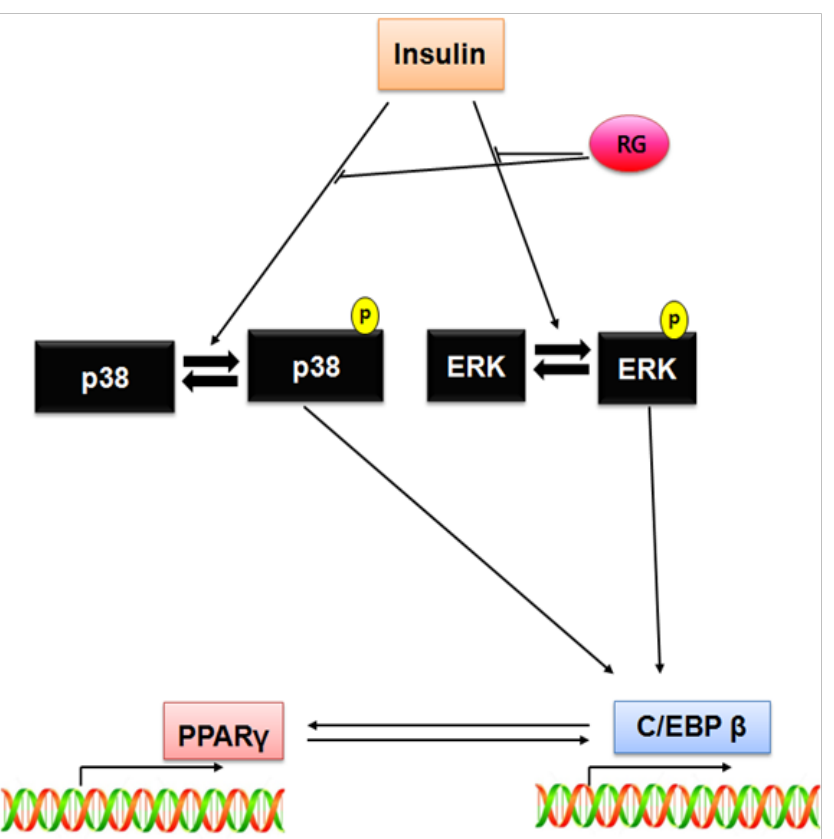

Figure 5: Inhibition pathway of RG in 3T3-L1 adipocyte differentiation

\section{Conclusions}

Our data demonstrate that RG inhibition of adipocyte differentiaton through to regulation of MAPK activation. To regulation of MAPK regulate, draw reduction of adipogenic transcriptional factor $(\mathrm{C} / \mathrm{EBP} \alpha, \mathrm{C} / \mathrm{EBP} \beta$ and PPAR $\gamma)$ and adipogenic makers (adipsin, p21) expression. Via these mechanisms $\mathrm{RG}$ is inhibition to accumulation of lipid in adipocyte. Our data suggest that RG can be used in a treatment of adipocyte. 


\section{Acknowledgements}

This research was supported by the Ministry of Agriculture, Food and Rural Affairs (MAFRA), through the 2016 Healthy Local Food Branding Project of the Rural Resources Complex Industrialization Support Program.

\section{References}

1. Wasan, K. M., Subramanian, R., Kwong, M., et al. Poloxamer 407-mediated alterations in the activities of enzymes regulating lipid metabolism in rats. (2003 ) J Pharm Pharm Sci 6(2): 189-197.

2. Yun, T. K. Brief introduction of Panax ginseng C.A. Meyer. (2001) J Korean Med Sci 16 Suppl: (S3-S5).

3. Choi, K. T. Botanical characteristics, pharmacological effects and medicinal components of Korean Panax ginseng C A Meyer. (2008) Acta Pharmacol Sin 29(9): 1109-1118.

4. Qi, L. W., Wang, C. Z. Yuan. C. S. Isolation and analysis of ginseng: advances and challenges. (2011) Nat Prod Rep 28(3): 467-495.

5. Bang, H., Kwak, J. H., Ahn, H. Y., et al. Korean red ginseng improves glucose control in subjects with impaired fasting glucose, impaired glucose tolerance, or newly diagnosed type 2 diabetes mellitus. (2014) J Med Food 17(1): 128-134.

6. Kwak, Y. S., Kyung, J. S., Kim, J. S. et al. Anti-hyperlipidemic effects of red ginseng acidic polysaccharide from Korean red ginseng. (2010) Biol Pharm Bull 33(3): 468-472.

7. Du, Xiao, F., Jiang, C. Z., Wu, C. F. et al. Synergistic immunostimulatory effect of pidotimod and red ginseng acidic polysaccharide on humoral immunity of immunosuppressed mice. (2008) Pharmazie 63(12): 904-908.

8. Lee, Y. J., Han, J. Y. Lee, C. G. et al. Korean Red Ginseng saponin fraction modulates radiation effects on lipopolysaccharide-stimulated nitric oxide production in RAW264.7 macrophage cells. (2014) J Ginseng Res 38(3): 208-214.

9. Lee, M. R., Yun, B. S., In, O. H. et al. Comparative study of korean white, red, and black ginseng extract on cholinesterase inhibitory activity and cholinergic function. (2011) J Ginseng Res 35(4): 421-428.

10. Chung, I. M., Kim, Y. O. . Ali, M. et al. Triterpene glycosides from red ginseng marc and their anti-inflammatory activities. (2014) Bioorg Med Chem Lett 24(17): 4203-4208.

11. Bak, M. J., Hong, S. G., Lee, J. W. et al. Red ginseng marc oil inhibits iNOS and COX-2 via NFkappaB and p38 pathways in LPS-stimulated RAW 264.7 macrophages. (2012) Molecules 17(12): 13769-13786.

12. Vestberg, D., Rosengren, A., Olsson, M. et al. Relationship between overweight and obesity with hospitalization for heart failure in 20,985 patients with type 1 diabetes. (2013) Diabetes Care 36(9): 2857-2861.

13. Gorter, P. M., van Lindert, A. S. de Vos, A. M. et al. Quantification of epicardial and peri-coronary fat using cardiac computed tomography; reproducibility and relation with obesity and metabolic syndrome in patients suspected of coronary artery disease. (2008) Atheroscl 197(2): 896-903.
14. Palacios-Martinez D, Garcia-Alvarez, J. C. Montero-Santamaria, N. et al., Macrocytic anemia and thrombocytopenia induced by orlistat. (2013) Int J Endocrinol Metab 11(4): e6721.

15. Manning, S., Pucci, A., Finer. N. Pharmacotherapy for obesity: novel agents and paradigms. (2014) Ther Adv Chronic Dis 5(3): 135-148.

16. Hirosumi, J., Tuncman, G.,. Chang, L. A central role for JNK in obesity and insulin resistance. (2002) Nature 420(6913): 333-336.

17. Gregoire, F. M., Smas, C. M., Sul. H. S. Understanding adipocyte differentiation. (1998) Physiol Rev 78(3): 783-809.

18. Maekawa, T., Jin, W., Ishii. S. The role of ATF-2 family transcription factors in adipocyte differentiation: antiobesity effects of p38 inhibitors. (2010) Mol Cell Biol 30(3): 613-625.

19. Gwon, S. Y., Ahn, J. Y., Jung, C. H., et al. Shikonin suppresses ERK $1 / 2$ phosphorylation during the early stages of adipocyte differentiation in 3T3-L1 cells. (2013) BMC Complement Altern Med 13: 207.

20. Bost, F., Aouadi, M., Caron, L. et al., The role of MAPKs in adipocyte differentiation and obesity. (2005) Biochimie 87(1): 51-56.

21. Schild, R. L., Sonnenberg-Hirche, C. M., Schaiff, W. T. et al. The kinase $\mathrm{p} 38$ regulates peroxisome proliferator activated receptor-gamma in human trophoblasts. (2006) Placenta 27(2-3): 191-199.

22. Fajas, L. Adipogenesis: a cross-talk between cell proliferation and cell differentiation. (2003) Ann Med 35(2): 79-85.

23. Cho, H. M., Kang, Y. H. Yoo, H. et al. Panax red ginseng extract regulates energy expenditures by modulating PKA dependent lipid mobilization in adipose tissue. (2014) Biochem Biophys Res Commun 447(4): 644-648.

24. Chung, S. I., Rico, C. W., Kang. M Y. Comparative study on the hypoglycemic and antioxidative effects of fermented paste (doenjang) prepared from soybean and brown rice mixed with rice bran or red ginseng marc in mice fed with high fat diet. (2014) Nutrients 6(10): 46104624 .

25. Barak, Y., Nelson, M. C. Ong, E. S. et al. PPAR gamma is required for placental, cardiac, and adipose tissue development. (1999) Mol Cell 4(4): 585-595.

26. Subbarayan, V., Xu, X. C., Kim, J. et al., Inverse relationship between 15-lipoxygenase-2 and PPAR-gamma gene expression in normal epithelia compared with tumor epithelia. (2005) Neoplasia 7(3): 280293.

27. Payne, V. A., Au, W. ,Lowe, C. E., S et al. C/EBP transcription factors regulate SREBP1c gene expression during adipogenesis. (2010) J Biochem 425(1): 215-223.

28. Rosen, E. D., MacDougald. O. A. Adipocyte differentiation from the inside out. (2006) Nat Rev Mol Cell Biol 7(12): 885-896.

29. White, U. A., Stephens. J. M. Transcriptional factors that promote formation of white adipose tissue. (2010) Mol Cell Endocrinol 318(12): $10-14$.
Ommega Online Publishers

Journal Title: Journal of Diabetes and Obesity (JDO)

Journal Short Name: J diabetes Obes
Journal ISSN: 2356-0494

E-mail: diabetes@ommegaonline.com

Website: www.ommegaonline.org 